\title{
Nursing approaches for pain diagnosis and classification of outcomes*
}

\section{Condutas de enfermagem no diagnóstico da dor e a classificação dos resultados}

Simone Regina Alves de Freitas Barros ${ }^{1}$, Ana Paula dos Santos Albuquerque ${ }^{1}$

${ }^{*}$ Received from College of Northern Paraná, PR, Brazil.

DOI 10.5935/1806-0013.20140021

\section{ABSTRACT}

BACKGROUND AND OBJECTIVES: Nurses, as members of the health team, have to play their role to control pain, and are accountable for diagnostic evaluation, intervention and monitoring of treatment outcomes. This study aimed at identifying nursing students' approaches on interventions as from pain nursing diagnosis, according to taxonomy II of the North American Nursing Diagnosis Association and the association of nursing outcomes regarding interventions.

METHODS: This is a transversal and quantitative study using as tool a clinical case. Studied sample was made up of 60 nursing students in the last graduation period. The research was carried out in two Public Universities, both in the state of Pernambuco.

RESULTS: From the evaluated sample, most students (69\%) have not presented interventions for the clinical case. From $31 \%$ presenting interventions, only $58 \%$ have presented expected outcomes, according to Nursing Outcomes Classification based on planned interventions. It is worth stressing the large number of students (42\%) who have not performed the Nursing Outcomes Classification.

CONCLUSION: Based on the results of this research, it is necessary a reflection about painful patients' evaluation, as well as about nursing approaches needed to solve or minimize such problem. One should add to this research the lack of qualification of future professionals and the need to change posture with regard to technical-scientific knowledge required by the profession.

Keywords: Nursing care, Nursing diagnosis, Pain.

1. College of Northern Paraná, PR, Brazil.

Submitted in August 08, 2013.

Accepted for publication in May 08, 2014.

Conflict of interests: none.

Correspondence to:

Simone Regina Alves de Freitas Barros

Av. Jonas Camelo, 316 - Centro

56520-000 Buíque, PE, Brasil.

E-mail: simoninhabarros2010@hotmail.com

(c) Sociedade Brasileira para o Estudo da Dor

\section{RESUMO}

JUSTIFICATIVA E OBJETIVOS: $\mathrm{O}$ enfermeiro deve exercer seu papel no controle da dor, e tem responsabilidade na avaliação diagnóstica, na intervenção, na monitorização dos resultados e no tratamento, como membro da equipe de saúde. O objetivo deste estudo foi identificar as condutas de acadêmicos de enfermagem sobre as intervençóes a partir do diagnóstico de enfermagem de dor, segundo a taxonomia II da North American Nursing Diagnosis Association e a associação dos resultados de enfermagem perante as medidas de intervenção.

MÉTODOS: Estudo do tipo transversal de natureza quantitativa, utilizando como instrumento um caso clínico. A amostra estudada foi composta por 60 acadêmicos de enfermagem cursando o último período da graduação. A pesquisa deu-se em duas Instituiçóes de Ensino Superior Públicas, ambas localizadas no estado de Pernambuco.

RESULTADOS: Da amostra analisada a maior proporção dos acadêmicos (69\%) não apresentou intervençôes para o caso clínico. Dos $31 \%$ que apresentaram intervençôes, apenas $58 \%$ apresentaram os resultados esperados, segundo a Classificação dos Resultados de Enfermagem com base nas intervençóes planejadas. Vale ressaltar o número expressivo de acadêmicos (42\%) que não realizaram a Classificação dos Resultados de Enfermagem.

CONCLUSÁO: Baseando-se nos resultados desta pesquisa torna-se necessária uma reflexão sobre a avaliação do paciente com dor, assim como sobre as condutas de enfermagem necessárias para suprir ou amenizar tal problemática. Acrescenta-se a esta pesquisa a falta de preparo dos futuros profissionais e a necessidade de mudança de postura perante o domínio técnico-científico exigido pela profissão.

Descritores: Cuidados de enfermagem, Dor, Diagnóstico de enfermagem.

\section{INTRODUCTION}

To help universal understanding and communication, the International Association for the Study of Pain (IASP) has put together in 1976 a sub-committee of pain Taxonomy. Thereafter, pain started to be defined by IASP as "an unpleasant sensory and emotional experience associated to real or potential tissue injury or described in terms of such injury"1.

In Brazil, it is estimated that chronic pain affects 30 to $40 \%$ of the population and is the major reason for absenteeism, 
medical leaves, early retirement, labor indemnities and low productivity, being considered a public health problem ${ }^{2}$. So, pain control is a mandatory public health practice due to health services demand and unfavorable social impact on the quality of life of painful patients. It is important to stress that the lack of adequate diagnosis and treatment during the acute stage may favor pain chronicity and worsening of clinical presentation. So, pain complaint should always be valued and respected in any health assistance level ${ }^{2}$. For such, pain control should be a nurses' concern.

The independent and collaborative action of such professionals involves pain identification, characterization of the painful experience in all its domains, checking its repercussions on patients' biological, emotional and behavioral functioning, identifying factors contributing to pain improvement or worsening, choosing treatment alternatives and checking the effectiveness of implemented therapies ${ }^{3}$.

A study about knowledge and attitudes of 120 nurses when handling pain has shown that, in average, $62 \%$ of these professionals had not enough knowledge about pain and analgesia ${ }^{3}$.

A different study evaluating the technical-scientific mastering of nursing students when dealing with pain has shown that $50 \%$ of students had regular knowledge and 33\% insufficient knowledge. So, it is considered that the technical-scientific mastering could contribute to better painful patients' assistance $^{4-10}$.

It is known that nursing diagnoses classification by the North American Nursing Diagnosis Association (NANDA) has contributed both to their growth and improvement and to the development of a system to classify diagnoses in taxonomy. Nursing Interventions Classification (NIC), with a standardized language to describe nursing procedures, and Nursing Outcomes Classification (NOC), based on a standardized language of nursing outcomes resulting from interventions, are also important ${ }^{5}$.

The identification of specific diagnoses is critical because as from them one may develop the most accurate possible intervention plan. The objective of the plan is to direct treatment and so better meet patients' needs, contributing to knowledge building and nursing aggrandizement. According to the literature, NANDA taxonomy implies a systematic arrangement of nursing phenomena listed by groups and based on common features of such phenomena ${ }^{5}$.

Nursing diagnoses classification system represents a search for a new reference centered in nursing science knowledge. This search is increasing as a way to face pressure and define the body of knowledge and skills essential for the nursing practice ${ }^{5}$.

A literature review considering scientific articles, theses and dissertations, in the LILACS database and aiming at reviewing NIC knowledge available in the scientific literature from January 1980 to January 2004 has indicated the possibility of carrying out several other studies which may contribute to reveal new NIC-related knowledge aspects ${ }^{6}$.

In light of the above, it is clear the relevance of nursing di- agnosis because it brings benefits not only to professionals and patients, but also to the institution. So, nursing diagnoses benefit all, because they direct nursing assistance to the needs of each patient, help the choice of more adequate interventions, objectively record patients' reactions and allow the subsequent nursing care evaluation ${ }^{7}$.

For such, our study went after objectives to identify nursing students' attitudes toward NIC as from nursing pain diagnoses, according to NANDA's taxonomy II and Outcomes Classification (NOC) resulting from intervention measures.

\section{METHODS}

This is a transversal quantitative study aiming at describing nursing students' behavior with regard to establishing interventions and their association to results as from the use of pain diagnosis presented by a clinical case, carried out in two public Colleges, both in the State of Pernambuco.

Sample was made up of 60 students in the last period of the nursing graduation course.

Participants were explained about the study methodology and expected objectives with the above-mentioned subject. There were no refusals and all participants have signed the Free and Informed Consent Term (FICT).

The study was developed according to resolution 196 from October 1996 of the National Health Council and in compliance with the Declaration of Helsinki.

Data were collected during the first semester of 2008 by means of a questionnaire with a clinical case with nursing diagnosis of acute pain. Participants were asked to develop nursing interventions and classify the case, which is described below.

Clinical Case: Female patient, 27 years old, reporting that 2 days ago started with lack of appetite associated to abdominal pain located in the epigastrig region. At initial evaluation she had temperature of $37.9^{\circ} \mathrm{C}$, pulse $100 \mathrm{bpm}$, blood pressure $100 \times 60 \mathrm{mmHg}$, pale $(+/+4)$, normal cardiopulmonary auscultation. Abdomen was sensitive to palpation, tense, with more severe pain in right iliac fossa (Mc Burney point) and sudden positive decompression. Hydroaerial sounds were decreased. Digital rectal and vaginal examination was normal. Physician's diagnostic hypothesis: Acute abdomen?

Question 1: As from described information, develop nursing pain diagnosis, interventions for the diagnosis and as from these the expected results for the diagnosis, as recommended by the nursing assistance systematization.

The electronic spreadsheet Microsoft Excel" was used to develop the database, which has allowed the organization of data in figures. Statistical package SSPS (Statistical Package for the Social Sciences, 13.0) was used for statistical analysis. Data obtained reflect a statistical reliability level of $95 \%$.

This study was approved by the Research Ethics Committee, University of Pernambuco, under opinion 017/2008. 


\section{RESULTS}

After information obtained with the data collection tool and treatment of data, propositions which had better responded to the objectives of this study were selected. Studied population corresponded to students of the last nursing graduation period, being $83 \%$ females and 17\% males. Age has varied between 17 and 30 years. The curriculum of both institutions had the Nursing Assistance Methodology discipline, which teaches assistance systematization and, as a consequence, the development of nursing diagnosis as a stage of the care systematization process.

Figure 1 shows nursing students' behavior with regard to the presentation of approaches for the presented acute pain clinical case.

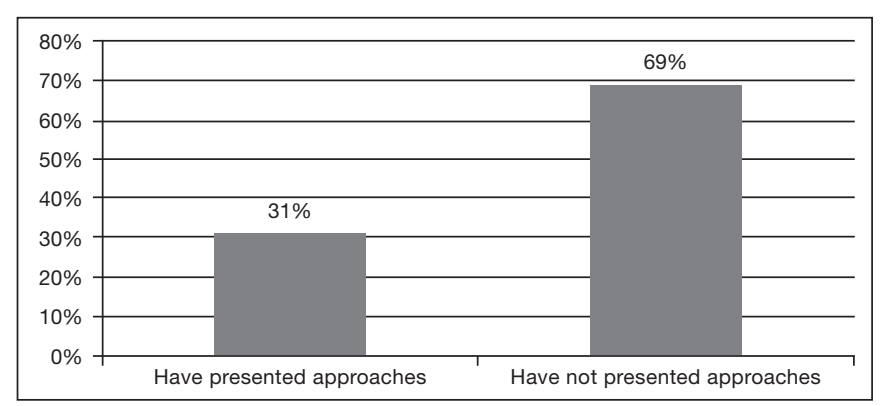

Figure 1. Nursing interventions with regard to pain

As from presented nursing interventions, figure 2 shows the association of nursing results, according to NOC, based on planned interventions for the clinical case. Only 58\% of $31 \%$ of students who presented nursing approaches for pain have carried out NOC based on planned interventions.

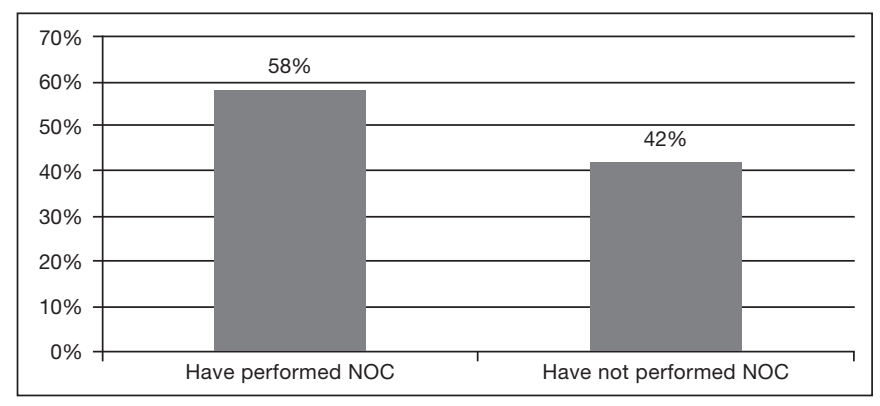

Figure 2. Association of interventions versus classification of results

NOC: Nursing Outcomes Classification.

\section{DISCUSSION}

NIC is a nursing classification developed by a group of researchers from the Iowa University (USA) since 1986 to identify and describe what nurses do. It was developed to portrait the care given to patient, family and community, and to describe nursing interventions and treatments in all care and specialties environments ${ }^{8}$.

Intervention is defined as any treatment, based on clinical judgment and knowledge, carried out by nurses to improve results obtained by patient, family and community. NIC is considered useful for clinical documentation, communication among professionals about the care given, insertion of data on systems, effectiveness research, productivity measures, competence and reimbursement evaluation ${ }^{8}$.

For such, nurses may standardize practice with specific language, after the nursing diagnosis, by using NIC, as seen in table 1, which shows nursing interventions for acute or chronic pain diagnosis. Such information is based on the study by Rigotti and Ferreira ${ }^{4}$, for being the most recent publication addressing this subject.

NIC is a comprehensive classification because it encompasses from generalist practices to specialty and standardized areas. So, links between NANDA and NIC help diagnostic foundation and clinical decisions made by nurses ${ }^{5}$. As seen in this study, $58 \%$ of students have not presented approaches (NIC) for pain relief. It is also possible to observe that a significant number of studies bring interventions for the specialized clinic and have few interventions to treat pain in its general context. Studies show that acute pain may favor its chronicity and clinical presentation worsening if there are no adequate interventions ${ }^{2}$.

NIC is an important tool to favor nursing teaching, research and assistance, in addition to offering new possibilities for investigating classification systems, standardized nursing language, nursing IT and nurses' action spectrum, among others ${ }^{6}$.

It is known that NOC is used to evaluate nursing interventions results. Its objectives are: identification, labeling, validation and classification of results, and testing measurement procedures for results and indicators. In this classification, the nursing team works with results most influenced by nursing interventions ${ }^{5}$.

This study has shown that an expressive number of students (42\%) have not performed NOC and such data have no comparative parameters in recent literature. It is believed that institutions graduating nursing professionals are probably not preparing their future nurses to deal with pain in the clinical practice. The fundamental objective is that students understand acute or chronic painful phenomenon and its biopsychosocial repercussions, and are aware of the importance of pain control ${ }^{4}$.

Nurses shall play their role in pain control and be accountable for diagnostic evaluation, intervention and monitoring of treatment results, for communicating information about patients' pain, as members of the health team ${ }^{3}$. Nursing is, undoubtedly, the team with closest contact with patients during their hospitalization, since nurses have a strategic position, that is, it is the team acting close to patients, participating on routines and procedures around-the-clock, experiencing pain and distress with patients and their relatives, contributing to comfort and relief of such situations? 
Table 1. Pain control of nursing interventions classification (NIC) ${ }^{4}$

Definition: Pain relief or decrease to a level of comfort acceptable by patients

Activities:

Carry out a comprehensive pain identification, to include site, characteristics, onset/duration, frequency, quality, pain intensity or severity and triggering factors.

Observe non verbal indicators of discomfort, especially in patients unable to effectively communicate.

Assure accurate analgesia to patients.

Use therapeutic communication strategies to recognize pain and transmit acceptance of response to pain.

Analyze cultural influences on response to pain.

Determine the impact of painful experience on quality of life (e.g.: sleep, appetite, activity, cognition, mood state, relationships, professional performance and responsibility of roles).

Evaluate previous pain experiences so as to include individual or family history of chronic pain or resulting disability, when adequate.

Evaluate with patients and health care team the efficacy of pain control measures which have been used.

Help patients and relatives to look for and offer support.

Use adequate survey method allowing the monitoring of changes in pain and helping the identification of real and potential receptor factors (e.g.: flowchart, records in a diary).

Determine the needed frequency to survey patients' comfort and implement a monitoring plan.

Offer information about pain, that is, its causes, duration and anticipated discomforts caused by procedures.

Control environmental factors able to influence patients' response to discomfort (e.g., room temperature, lighting, sounds).

Decrease or eliminate factors which trigger or worsen pain experience (e.g., fear, fatigue, monotony and lack of information).

Understand patients' willingness to participate, their ability to participate, their preferences, support of relevant people as to the method and contraindications when selecting a pain relief strategy.

Select and implement a variety of measures (e.g., pharmacological, non-pharmacological, interpersonal) to help pain relief, when adequate.

Analyze pain type and source when selecting a relief strategy.

Encourage patients to monitor their own pain and adequately interfere.

Teach the use of non-pharmacological techniques.

Cooperate with patients, with relevant people and other health professionals in the selection and implementation of non-pharmacological pain relief measures, when adequate.

Offer relief with prescribed analgesics.

Implement the use of patient-controlled analgesia, when adequate.

Use pain control measures before it gets worse.

Medicate before activities to improve participation, but evaluate sedation-related risks.

Assure pre-treatment analgesia and/or non-pharmacological measures before painful procedures.

Check with patients their level of discomfort, observe medical record changes and inform other health professionals assisting patients.

Evaluate the effectiveness of pain control measures by means of constant survey of the painful experience.

Institute and modify pain control measures based on patients' response.

Promote adequate rest/sleep to provide pain relief.

Encourage patients to discuss their painful experience, when adequate.

Notify the physician if measures are not successful or if current complaint is a significant change as compared to patients' previous painful experience.

Inform other health professionals/relatives about non-pharmacological strategies that are being used by patients to encourage preventive pain control approaches.

Use a multidisciplinary approach to control pain, when adequate.

Analyze referrals of patients, relatives and relevant people to support groups and other resources, when adequate.

Offer adequate information to promote family knowledge about painful experience response and painful experience itself.

If possible, incorporate family in the pain relief modality.

Monitor patients' satisfaction with pain control at specific intervals.

The major limitation of this research is that there are no studies about NIC for pain in major databases, such as Scielo, more specifically in the last five years. Identified studies have approaches directed to factors intervening with a specific pain such as "joint pain relief" or "differential pains diagnosis", which does not allow including NIC and NOC in an acute or generalized chronic scenario.
Our results show the possibility of producing NIC and, consequently, NOC knowledge in Brazil and call the attention to the importance of studies addressing such taxonomy, generating new knowledge and raising questions, and which may, in some way, contribute with one more aspect related to Brazilian nursing progress ${ }^{6}$. 


\section{CONCLUSION}

In light of the above, the relevance of the subject for nursing students and professionals is noticed, in addition to few studies in this area, which raises the interest of students and professionals since this subject defines the body of knowledge and skills essential for the nursing practice.

It is known that NIC depends on nursing diagnosis and it is from this point that it is possible to identify conceptual gaps which validate nursing functions and increase their professional autonomy. NIC and NOC present cause and effect inter-relations of observed alterations, helping the establishment of goals, the adoption of nursing approaches and the evaluation of assistance.

Based on our results, it is necessary a reflection about painful patients' evaluation, as well as about nursing approaches to eliminate or minimize such problem, in addition to lack of professional qualification and the need to change the posture of nursing students with regard to their qualification.

\section{REFERENCES}

1. Pavani NJ. Dor no câncer. Rev Bras Cancerol. 2000;3(12):42-52.

2. Pinto LS, Casa EC. Sistematização da assistência de enfermagem no tratamento da dor oncológica. Rev Enferm UNISA. 2005;6(1):64-9.

3. Ruviaro L, Filippin LI. Prevalência de dor crônica em uma Unidade Básica de Saúde de cidade de médio porte. Rev Dor. 2012;13(2):128-31.

4. Rigotti MA, Ferreira AM. Intervençóes de enfermagem ao paciente com dor. Arq Ciênc Saúde. 2005;12(1):50-4.

5. Rocha LA, Maia TF, Silva LF. Diagnósticos de enfermagem em pacientes submetidos à cirurgia cardíaca. Rev Bras Enferm. 2006;59(3):321-6.

6. Napoleão AA, Chianca TC, de Carvalho EC, Dalri MC. [Analysis of publications on Nursing Interventions Classification (NIC) from 1980 to 2004]. Rev Lat Am Enfermagem. 2006;14(4):608-13. Portuguese.

7. Lopes RA, Macedo DD, Lopes MH. [The most frequent nursing diagnoses in an oncology admission unit]. Rev Lat Am Enfermagem. 1997;5(4):35-41. Portuguese.

8. McCloskey JC, Bulechek GM, (editors). Classificaçấo das intervençôes de enfermagem (NIC). $3^{\mathrm{a}}$ ed. Porto Alegre: Artmed; 2004.

9. Francischinelli AG, Modena T, Morete MC. Conhecimento dos profissionais de enfermagem quanto às medidas nấo farmacológicas para o alívio da dor nos pacientes pediátricos. Rev Dor. 2009;10(1):19-24.

10. Barros SR, Pereira SS, Almeida Neto A. A formaçăo de acadêmicos de enfermagem quanto à percepção da dor em duas instituiçôes de ensino superior. Rev Dor. 2011;12(2):131-7. 